\title{
The environmental responsibility as integrated of the future social pedagogenic person's quality
}

\author{
L. P. Dobrovolskaya ${ }^{1}$, I. S. Tretyakova ${ }^{2}$ \\ ${ }^{1}$ Boghdan Khmelnitskyi Melitopol State Peagogical University, Melitopol, Ukraine \\ Corresponding author. E-mail: dobrov5335@ukr.net \\ ${ }^{2}$ Municipal institution of education «Educational Complex №72» School of I-III degrees - Preschool Educational Establishment \\ (kindergarten)» of the Dnipro City Council, Dnipro, Ukraine \\ Corresponding author. E-mail: tretyakovairena@gmail.com
}

Paper received 24.06.18; Accepted for publication 30.06.18.

https://doi.org/10.31174/SEND-PP2018-173VI71-12

\begin{abstract}
The article is devoted to the problem of forming the ecological responsibility of students-social educators in the of a new educational paradigm's context. The scientific-theoretical and methodological principles of the problem are highlighted there. The ways of ecological world outlook formation, future specialists of social sphere responsibility in the system of education are revealed. The authors analyzed the category of ecological responsibility as a scientific concept and subject of research. The scientific approaches to the definition of responsibility and environmental responsibility are considered, which extends the boundaries of understanding the origins and peculiarities of its formation in future social educators. The leading social, psychological and pedagogical factors contributing to the formation of ecological responsibility, ecological world outlook, ecological beliefs and ecological installations of future specialists are determined. There are presented the main topics of the content of the special course «Psychology of the responsibility of the future specialist» in the article. It is stated about implementation of the author's comprehensive program of adaptation of the first-year students «Health-Motivation-Professional» and correctional training aimed at forming a higher level of students-social pedagogues' environmental responsibility. The results of the empirical ecological installations research, the level of responsibility indicators and the degree of formation of environmental competence components from future specialists are presented, directions of further research on the implementation ideas of noosphere in the educational space of the University are outlined.

Keywords: ecological education, ecologization, responsibility, ecological responsibility, environmental believes, ecological competence, ecological installations.
\end{abstract}

Introduction. Without nature, people can't exist, and the resolution of environmental conflicts should be solved only through harmonization of human relations with society and the natural environment. Today, unfortunately, humanity, which is characterized by a purely consumer outlook and selfish material values, mercilessly exploits nature and destroys its resources. «The sense of dignity fades in the people, in which the love of wealth is inflamed» - K. Helvetius emphasized. The development and formation of environmental responsibility, environmental competence, environmental consciousness and self-awareness is the only effective way out of the ecological crisis. The combination of the modern Ukrainian youth upbringing with national cultural sources, overcoming the gap between the cultural, spiritual, scientific and educational spheres of human require fundamental changes and the search for effective approaches to the training of social educators. The transformation experienced by Ukrainian society today is bound to affect all spheres of life and student youth. Modern students do not have a sufficient level of responsibility, which in turn affects not only the quality of the acquisition of the necessary knowledge, skills and abilities, but also their personal and professional development. It should be noted that despite the extensive study of the aforementioned problem by various scientific schools, the question of forming the environmental responsibility of the personality of the future social teacher is not sufficiently developed in pedagogy, psychology. Therefore, the study of the formation of the ecological worldview problem, ecological responsibility and determination of factors of environmentaly of the cultural and educational space become actualized.

Discription. In order to determine the role of responsibility in spiritual development and the professional development of a future specialist, it is necessary to study this problem from all aspects, and more precisely, it is necessary to analyze existing approaches to determining responsibility, environmental responsibility, spiritual devel- opment and professional self-improvement of the individual. Psychological aspects of responsibility as integral quality of personality were disclosed in the works of M. Levkivsky, K. Muzdibayeva, M. Savchina, L. Tatomyr, M. Drigus and others. The most extensive analysis of the problems of personality's spiritual development was conducted by M. Boryshevsky, O. Kulchitska, E. Pomytkin, V. Ponomarenko, M. Savchyn, W. James, K. Rogers, E. Fromm and others.

It is advisable to turn to the views of I. Maltseva, who notes that there is no alternative to the ecological imperative both in the worldview and in technology, therefore the formation of ecological consciousness is an important task of education. Education must contain humanistic ideas and form a new type of culture, oriented towards environmentaly, a careful attitude to nature [3, p. 177].

Klyag I., Levochkina A., Screbec V. are states that the ecologization of consciousness gives each person the right to health and productive life in harmony with nature, to live in an environmentally friendly and supportive environment. The psychology of the environment is bound to be associated with the psychology of eco-conservation because they explore the connection between a person and an «unsociable» environment. In the research work of Chernova N. and Belova A. had noticed that ecological thinking should become an integral part of the every young person's thinking. The understanding this should be the basis of future social educators' environmental training and vocational education [6, p. 270-271]. Of course, the exacerbation of global problems makes it necessary to turn to humanistic concepts, since the significance of humanistic ideas is stimulated not only by moral considerations, but also becomes the basis for the education of society and of all mankind.

The purpose of the article is to highlight the main approaches of ecological education; present the of an empirical study results on the determination of indicators for the ecological installations level, the degree of formation 
of components of environmental liability. Before modern higher educational institutions there is a task to form a specialist who can freely and deliberately realize in the modern world, carry responsibility for the consequences not only of their actions, but also for their own inactivity. The educational process should be aimed at creating the optimal conditions for the formation of the needs and desires of future specialists to communicate with nature, to develop the interest of students in the knowledge of the laws of nature, the awakening of their conviction in the social conditionality of the relation of man to nature, man to man.

Materials and methods: a) theoretical: studying and analysis of philosophical, psychological, pedagogical literature, analysis and synthesis of experimental data, standards and curriculum; b) empirical: psychological and pedagogical experiment, methods of psychodiagnostic such as «Methodology for determining liability» (author Ostacheva M.), «Self-assessment of ecological competence methodology» (Ermakova D.), «The questionnaire ecocentric and anthropocentric installations relative to the environment» (Thompson S., Burton M. in adaptation Kryazh I., Andronnikova K.), quantitative and qualitative analysis of the results.

Results and analysis. "Managing nature is possible if she obey» stated Bacon F., an English philosopher, the founder of English materialism. Kant I. referred to the problem of responsibility, who stated that freedom brings people over the whole world, but he does not identify freedom with tyranny, oppression. In each sphere of the educational process, it is necessary to have a clear idea of the ways in which the process of education and education forms the ecological worldview, environmental responsibility and stimulates the spiritual development of the individual. This process can be realized by means of a radical review of goals, principles, content, methods and forms of learning, the rejection of authoritarian pedagogy and the transition to humanistic learning goals.

Today it is extremely necessary to find out the methodology in the system of pedagogical theory and practice, the definition of anthropology as the most pluralistic methodological approach of modern human knowledge. All this leads to a comprehension of existing contradictions both in worldview provision of pedagogical reality, and in the modern socio-cultural space, emphasizes the modern ukrainian philosopher Troizka T. [7, p. 89]. Vernadsky $\mathrm{V}$. noted that a person is capable of reproducing the equilibrium with the natural environment and his own dependence on the universe. According to the noosphere paradigm (sphere of reason), the center of the universe is placed responsible, humane, tolerant, responsible, capable of perceiving reality not only by reason, but also by heart [1, p. 98]. One of the first questions about the selfdetermination of free will, ethical values and responsibility of personality was developed by James W., Frankl W. The main authority before which each person bears responsibility, called the conscience [9, p. 126]. According to Fromm E., responsibility is not imposed from the outside of the duty, but the answer of the person to the request she has experienced, as her own problem. To be «responsible» means to be free and ready to answer [8, p. 27]. To the main modern scientific and methodological approaches to environmental education, scholars include axiological, cultural, activity and competence. The axiological approach involves the formation in the individual of the needs and abilities to implement a value relation to nature, people and to themselves as part of nature. From the standpoint of a cultural approach, ecological education is understood as a self-development sphere in the space of its cultural practices, the development of human creative potential. Activity approach to the organization of the environmental education process involves the inclusion of students in a variety of independent active activities, the search for solutions to them and direct activities on environmental protection. In the context of a competent approach, environmental knowledge and skills for independent and collective activities are used to solve social and environmental problems [6, p. 282-283].

It should be emphasized that the development of a higher level of students' environmental responsibility should take place in conditions ecologization of cultural and educational space. Most scientists consider ecologization as a process of penetration to the ecological approach and principles as a vital activity of each individual person, and in the life of the collective as a whole. Ecologization of educational space involves a significant transformation of all educational program components, including the nature of the interaction and interaction of participants in the educational process at the university. The priority tasks of ecological education and upbringing are: formation of ecological consciousness and person ecological culture based on a humane, valuable attitude to nature; development of skills, skills and experience of applying environmental knowledge in the practice of interaction with the surrounding world; creation of conditions for the formation and realization by the student of an active creative personal position in ecological activity, readiness for independent productive decisions in situations of moral and ethical ecological choice.

Famous scientists Dukhnovich O., Ushinsky K., Sukhomlynsky V. were engaged in studying the problems of environmental education. The problem of environmental education of future specialists has found some coverage in the research works of Mamaluia O., Tovazhyansky L., Romanovsky O. and others. Komendar V. had notes that the purposeful process of forming a students responsible attitude to nature in all types of educational socially useful activities and communicating with nature is the essence of environmental education and upbringing, which specify and deepen the main goal - the formation of ecological culture, environmental responsibility [2, p. 5]. Today, scientists are considering another approach to studying a person is the nature-centered, neoanthropological. This direction is connected with the development of a new ecological consciousness, the principles of which was formulated by the Norwegian scientist Ness P. This concept is a contrast to the anthropocentric approach and considers a person as part of nature, not a ruler, and considers its ecology in the context of the global environmental process. In turn, Commoner B. formed this principle as «all connected with all» It is necessary turns to the works by Nazaruk V., who defined the following sequence of components of ecological culture: ecological culture - ecological world perception - ecological consciousness - environmental beliefs - ecological self-awareness - ecological world-understanding - ecological activity - the ideal of human relations with nature.

Necessary and characteristic feature of the present is the increase of the level of social and pedagogical workers' ecological competence. Therefore, along with the disciplines that help future professionals to equip themselves with a specific tool for studying and solving the 
socio-pedagogical problem, a significant place in the preparation of socio-pedagogical staff has take aim at the development and formation of the ecological worldview, ecological thinking, environmental responsibility, ensuring the systematic and comprehensive scientific vision of the world and effective prediction of the students' educational and professional activities.

It is necessary to pay attention to the process of assimilation by future social educators' ecological knowledge, which must be accompanied by emotional experiences of the individual and contribute to the formation of its environmental beliefs as a core component of environmental responsibility. Environmental beliefs are a subjective relation of people to nature, which reveals knowledge of its significance for a person, the organization and evolution of nature, sensuously experienced and included in those aspects of consciousness associated with understanding the ideas of a lean human attitude to people and nature [5, p. 9].

Formation of ecological competences of future specialists in the conditions of balanced development must be carried out during the whole period of study in a higher educational institution on the basis of innovative, integrated approaches. In the basic programs of disciplines for the preparation of social educators, ways of harmonizing the relationships in the system «nature-humansociety» should be taken into account.

The most accurate definition of responsibility was given by Muzdibayev K., who called this consistent quality of personality the result of the integration of all mental functions of the individual, namely: subjective perception of the world, assessment of their own sensory resources, emotional attitude to duty and will [4, 19]. Here one should turn to the scholar's opinion that the central trend of the evolution of responsibility is manifested in the emergence of an additional internal control mechanism. Muzdibayev K. noted that responsibility primarily reflects the scale, the scope of personal tasks, the responsibilities of the individual.

Consequently, ecological responsibility is understood as the integral quality of the individual. This is a peculiar component of human consciousness, which is a personal's acceptance form of the existing system of responsible interdependence human and nature. This type of human responsibility is characterized by a higher degree of its positive attitude towards social needs. Environmental responsibility is based on a deep understanding of the person's actions and actions in accordance with the environment and is reflected in the awareness the role of society and human values in the ecological situation. One of the important problems of preparing a social teacher in a higher educational institution is an effective correlation in the study disciplines of integrating character and narrowprofile subjects. In the structure of professional activity of a social teacher, an important place belongs to both diagnostic and prognostic functions, the ability to implement personal, individual approaches, which is a priority in the system of social and pedagogical work. All this becomes possible only under the condition of comprehensive study and analysis of psychological and pedagogical, social phenomena.

To solve the above problem, we have made several effective steps towards the development and formation of a higher level of responsibility for future social educators. For this purpose, we developed and implemented a special course «Psychology of the future specialist's respon- sibility» in the educational process of the Bohdan Khmelnytskyi Melitopol State pedagogical University. The program of the course has planned topics that reveal the theoretical and methodological foundations to study of responsibility, the basic concepts and categories, principles and methods of investigating the responsibility of the future specialist in the process of professional training at the university. The thematic content of the course involves the study of eight topics: the concept of responsibility and responsible behavior; responsibility in the structure of the personality; typology of individual responsibility; structure and levels of responsibility; development of responsibility in ontogenesis; psychological mechanisms of responsible behavior; responsibility as an educational goal; psychological sense of responsibility as a factor of professional self-improvement of personality. Organization of work with future social educators became during the study of the course «Psychology of future specialists' responsibility». It confirms the possibility using this program of interactive character for the successful training of theorists and practitioners of social and pedagogical professions. As a practical block for the special course, a correction training was developed and implemented, aimed at the development and formation of a higher level of environmental responsibility of future social educators.

In 2017-2018, an empirical study of the level of future specialists' environmental responsibility conducted, involving 73 full-time and part-time students of the Bohdan Khmelnytskyi Melitopol State pedagogical university who are studying in the direction of preparation «Social Work». The results of the study showed that for the majority of students, the average level of disciplinary responsibility $(64,4 \%)$, responsibility for themselves $(67,1 \%)$ and others $(75,3 \%)$ are characteristic. The high level of disciplinary liability is set at $27,4 \%$, responsibility for itself $-24,7 \%$ and another $-19,2 \%$. In addition, there is a significant proportion of students with a low level of disciplinary responsibility $(6,8 \%)$, responsibility for themselves $(6,8 \%)$ and others $(4,1 \%)$. If we sum up the results of the study of the degree of formation of the environmental competence's components among students, it can be noted: the low level $-38,4 \%$, the middle level $39,7 \%$ and high level $-21,9 \%$. Thus, the feedback (the above-mentioned results) became for us - teachers a powerful signal for radical changes in approaches, methods, programs, organization of educational process. The person's inability to ecoreflexion leads to false and dangerous actions in the environment and in the personal life. Teachers of the university should direct students' perception of the environment to the ecological footprint. It will help determine our productive and safe stay in the present and in the future. In conditions of ecologization of educational space, it becomes obvious the need to find effective ways to create socio-psychological and pedagogical conditions that can provide the process of adaptation of students. That is why the authors (consultants of the for Psychological Service Center of Bohdan Khmelnytskyi Melitopol State pedagogical University) have developed a comprehensive program of adaptation of the first-year students «Health-Motivation-Professional». The system of successive events of the program is successfully implemented in the educational process of the university. Thus, the preparation of social pedagogues for humanistic principles is an integral part of the successful implementation of social, educational, and psychological tasks of the state social sphere. Social work is not without reason 
called «glue» of society, which facilitates the work of a huge social mechanism, so that he clearly worked, ensuring human rights and freedoms, the balance of the individual's interests, society and nature.

Conclusions to the main effective scientific and methodological approaches to environmental education, scholars include axiological, cultural, activity, competence, as well as anthropological, nature-centered, nonanthropological. In the course of the study, we identified the level of ecological installations affecting the formation of ecological responsibility: ecocentric, anthropocentric and environmental apathy. Unfortunately, most student youth are indifferent to environmental issues $(38,4 \%)$. Consequently, solving current problems of the global ecological crisis of cultural and educational space is only possible thanks to the active work of educators, who act as the engine for optimization and harmonization of the system «nature-human-society».

\section{ЛІТЕРАТУРА}

1. Духовний світ особистості майбутнього педагога в умовах екологізації культурно-освітнього простору: Монографія / [Добровольська Л.П., Третякова І.С., Федорова О.В. та ін., за заг. ред. Зарицької В.В.]. - Мелітополь: Вид-во МДПУ ім.. Б. Хмельницького. - 188 с.

2. Комендар В.І Проблеми екологічного виховання молоді: Навч. посібник / В.І. Комендар. - Ужгород: Вироб.-видав. комбінат «Патент», 1994. - 84 с.

3. Мальцева I.A. Екологічний імперетив в антропологічному вимірі // Освіта, наука і людина в XXI столітті: багатоаспектність антропологічного пізнання: [монографія] / [Авт.кол. за заг. ред. І.П. Аносова, Т.С. Троїцької]. Сімферополь: Таврія, 2008. - 300 с. -С. 161-189.

4. Муздыбаев, К. Психология ответственности / К. Муздыбаев / [под ред. В.Е. Семенова]. - Изд.2-е,доп. - Москва: URSS: Либроком, 2010. - 248 с.

5. Пустовіт Г.П. Філософсько-культорологічний аспект у екологічній освіті / Пустовіт Г.П. // Шлях освіти. - 2002. - № 3. - C.7-11.

6. Скребець В.О. Екологічна психологія: підручник / В.О. Скребець, І.І. Шлімакова. - К.: Видавничий Дім «Слово», 2014. $-456 \mathrm{c}$.

7. Троїцька Т.С. Методолого-освітній потенціал вітчизняної філософської антропології: до постановки проблеми використання в педагогічній теорії і практиці / Т.С. Троїцька // Пост Методика [Гол. ред.. С.Ф. Клепко]. - 2006. №7 (71) «Антропологізм в освіті: джерела, досягнення та перспективи». - С.88-93.

8. Фром Э. Человек для себя. Исследование психологических проблем этики / Эрих Фром / [перевод с английского Л.А. Чернышевой]. - Минск: Коллегиум, 1992. - 253 с.

9. Франкл В. Человек в поисках смысла: Сборник / Виктор Франкл / [Пер. с анг. и нем. Общ. ред. Л.Я Гозмана и Д.А. Леонтьева; вст.ст. Д.А. Леонтьева]. - М.: Прогресс, 1990. $-368 \mathrm{c}$.

\section{REFERENCES}

1. The future teacher personality's spiritual world in the conditions of ecologization of cultural and educational space: monograph / [Dobrovolskaya L. P., Tretyakova I.S., Fedorova O. V.]. - Melitopol: Bohdan Khmelnytskyi Melitopol State pedagogical university. $-188 \mathrm{p}$.

2. Komendar V. I. Problems of youth's environmental education / Comandar V. - Uzhgorod: Patent, 1994. - 84 p.

3. Malceva I. A. Ecological imperty in the anthropological dimension // Education, Science and Humanity in the XXI c.: Multidimensional anthropological Cognition: [monograph] / [Authors .col. per community Ed. I. Anosov, T. Troizka].Simferopol: Tavria, 2008. - P. 161-189.

4. Muzdybayev K. Psychology of responsibility / K. Muzdybaev / [ed. V. E. Semenov]. - Moscow: Librokom, 2010. - 248 p.

5. Pustovit G. P. Philosophical-cultural aspect in environmental education / Pustovit G. P. // Education path. - 2002. - No. 3. - P.7-11.

6. Skrabets V. O. Ecological psychology / V. Skrabets, I. Shlimakova. - K .: «Word», 2014. - 456 p.

7. Troizka T. S. Methodological and educational potential of the National Philosophical Anthropology: to the problem of use in pedagogical theory and practice / T. S. Troizka // Post methodology. - 2006. - №7 (71) «Anthropologism in education: sources, achievements and perspectives». - p.88-93.

8. Froude E. Man for yourself. The study of psychological problems of ethics / Erich Fröm / [translated from English L. A. Chernyshevoy]. - Minsk: Collegium, 1992. -253 p.

9. Frankl V.A Person in search of meaning: collection / V. Frankl. - Moscow: Progress, 1990. - 368 pp. 